\title{
STUDY ON THE HABITAT OF DEIRATONOTUS JAPONICUS AND AQUATIC ENVIRONMENT IN THE KITA RIVER, JAPAN
}

\author{
H. Yamanishi*, T. Kusuda**, S. Lee***, A. Hara**** and M. Hirata ${ }^{\#}$ \\ *Institute of Lowland Technolgy, Saga University, 1 Honjo, Saga, 840-8502, JAPAN \\ **Department of Urban and Environmental Eng., Faculty of Eng., Graduate School, Kyushu University \\ ***Department of Urban and Environmental Eng., Graduate of School, Kyushu University, JAPAN \\ ****Japan Regional Development Corporation, JAPAN \\ ${ }^{\#}$ Matsuo Consultants Co., Ltd., JAPAN
}

ABSTRACT

\begin{abstract}
Salt water from the sea flows up- and down-ward in tidal rivers due to tides. When mixing in a tidal river is relatively weak, a saltwater wedge is formed in it. The Kita river, the objective field in this study, located in eastern part of Kyushu island in Japan is in this state. When external forces work on an ecosystem, then changes might occur in response to them. The ecosystem in such a river is with more impact, because its aquatic zone in the tidal range is fragile and high in productivity. This study attempts to investigate the behavior of Deiratonotus japonicus, known as a rare species in the world, in association with saltwater wedge movement, to obtain relationships between water quality and hydraulic factors and to study the preferable environmental condition on the habitat of Deiratonotus japonicus. Based on field observations, the habitat of Deiratonotus japonicus has a distribution correlated to salinity and water temperature in the longitudinal direction, and riverbed materials and water surface elevation in the cross-section in the tidal range.
\end{abstract}

\section{KEYWORDS}

Deiratonotus japonicus; tidal river; saltwater wedge; ecosystem; habitat; aquatic environment

\section{INTRODUCTION}

The management of rivers in Japan has traditionally focused on protecting flood damage. Recently, people have become increasingly concerned with the natural and living environments, and now the river managers are trying to realize such concerns on the natural environment and landscape. In the Kita River, large-scale river improvement has been done since 1997 when the typhoon No.19 on September, 1997 brought a heavy rain. The improvement is pointed out to influence a lot of micro- and macro organisms. Therefore, the protection against disasters should be considered to minimize the influence to the present ecosystem. At first, in order to achieve the minimization, it is important to collect fundamental data on the environment suitable for the organisms inhabiting there. In addition, the changes of water quality and hydraulic factors in a tidal area cause complicated phenomena, and kinds of inhabiting creatures and habitation environment in such area are also various. Therefore, it is the high space of interest. Although, there are many investigations to evaluate the aquatic conditions, monitoring on a large or small scale to evaluate the tidal area in the Kita has hardly been done. Deiratonotus japonicus, a rare species in the Red Data Book of the Environmental Agency in Japan, is still ambiguous on habitat. This study paid attention to D. japonicus, and field surveys were carried out to make clear the relation between the habitation environment of $D$. japonicus and water quality and hydraulic factors in the Kita. Based on these survey results, influences to habitation of D. japonicus by water quality and major hydraulic factors in the Kita were discussed.

\section{SURVEYS AND EXPERIMENTS}

\section{Observation and water sampling}

Figure 1 illustrates an outline of the observation area in this study. The tidal area is comparatively gentle, 1/ 2000-1/1000 in riverbed gradient. Field measurements were carried out on October 10 ( spring tide) and No- 
vember 29, 1999 (neap tide). Various measurements were done hourly on ships at an interval of $1 \mathrm{~km}$ from the river mouth to $7 \mathrm{~km}$ point. Each ship was moored at the deepest spot in the cross section of each observation point. Measurement items are water depth, current velocity, $\mathrm{pH}$, conductivity, DO, water temperature, salinity, Chl-a, TN, $\mathrm{TP}$, and quantities of $\mathrm{C}$ and $\mathrm{N}$ of suspended solids. Current velocity was measured at an interval of $0.5 \mathrm{~m}$ depth at 0,3 , and $6 \mathrm{~km}$ points by using propeller type current meters or electromagnetic current meters. $\mathrm{pH}$, conductivity, turbidity, $\mathrm{DO}$, water temperature, and salinity were measured by using multi-water quality monitoring systems ( Horiba, Co.Ltd., U-20series). Their data were recorded at an interval of $0.5 \mathrm{~m}$ from the water surface, and $0.1 \mathrm{~m}$ away from both water surface and riverbed. Water column was divided into the upper and the lower layers. Water samples were obtained from 3 points, the central parts of the upper and the lower water layers and $0.1 \mathrm{~m}$ above the bottom.

\section{Deiratonotus japonicus}

D. japonicus is an endemic species in Japan in Ocypodidae (see photo 1). It inhabits brackish water areas south Japan and around $1 \mathrm{~cm}$ in the greatest shell width, dorsal surface is rather flat and hexagon-like with roundness. It has small scissor legs and several shallow ditches lying sideways on the shell. It is low in oxygen maintenance ability in air and active in water.

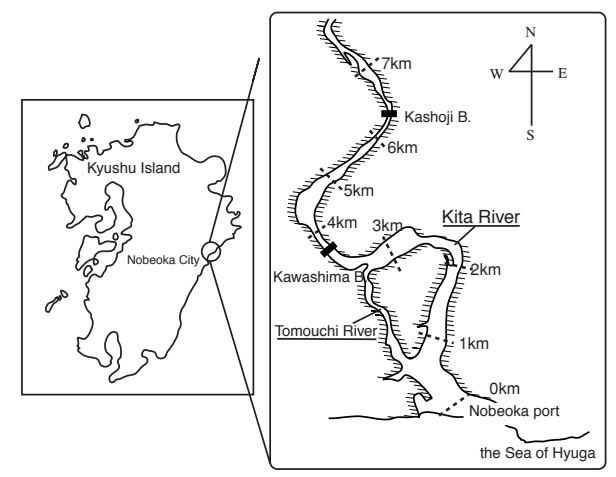

Fig.1 The Kita Estuary

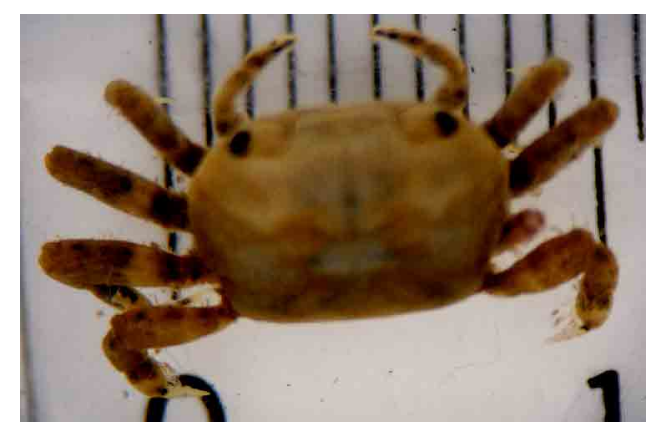

Phote 1 Deiratonotus japonicus

\section{Habitation density investigation of Deiratonotus japonicus}

Surveys were done in spring tides on July 30, 23-25 October and 8-9 November, 1999. D. japonicus was collected by use of a quadrat with a survey-net $(100 * 100 \mathrm{~cm}$ or $50 * 50 \mathrm{~cm})$. Density of $D$. japonicus was obtained as the number of individual per $1 \mathrm{~m}^{2}$. In addition, riverbed materials at surfaces, which are important as an environment factor and affect habitat of $D$. japonicus, were taken out with $D$. japonicus simultaneously and examined its size distribution.

\section{Long term survey on habitat in up- and down- stream edges}

In order to understand water quality changes between up- and down-stream edges which impacts population density of D. japonicus, $\mathrm{pH}$, electric conductivity, $\mathrm{DO}$ and water temperature were monitored from 9 to 23 , November ( spring neap spring) and from 25, Oct.to 8, Nov.,1999 ( spring neap $\sim$ spring) using water quality measuring instruments. Each monitoring was done for two weeks and the water measuring instruments stored data in an interval of 10 minutes. The instruments were installed near the riverine at low water in spring tide.

\section{Laboratory test of Deiratonotus japonicus}

We tested preference of $D$. japonicus in salinity. Two or three $D$. japonicus were immersed into water with different salinity and their survival period was examined. D. japonicus collected at $3.75 \mathrm{~km}$ spot( the lower part of Kawashima Bridge ) of the Kita on November 8 9, 1999. Salinity is set in three kinds of 0.5,10 and 30psu. Each water was made by mixing river water with sea water obtained in situ. In this experiment DO was kept higher than $8 \mathrm{mg} / \mathrm{l}$ in beakers to create similar situations to the habitat of $D$. japonicus.

\section{RESULTS AND DISCUSSION}

\section{Characteristics of the tidal area of the Kita}

According to the record at the Kumata observatory $(14.5 \mathrm{~km}$ point $)$ in the Kita, the daily averaged flow rates on 
Oct.10, 1999 ( spring tide) and Nov. 29, 1999 ( neap tide) were $3.94 \mathrm{~m}^{3} / \mathrm{s}$ and $1.86 \mathrm{~m}^{3} / \mathrm{s}$, respectively. They were comparatively less than $13.2 \mathrm{~m}^{3} / \mathrm{s}$, the annually averaged flow rate in the Kita.

Figure 2 shows salinity isopleth in a longitudinal direction in spring and neap tides. The interval of salinity isopleth lines in the figure is slightly narrower in neap tide than in spring tide for the region from the river mouth to $4 \mathrm{~km}$ upward. Then, in the neap tide, stratification of salinity progresses and a clear interface is formed. In other words, mixing in the vertical direction is depressed in neap tides. In addition, in case of neap tide, salt water mass of $30 \mathrm{psu}$ is found until the upper $6 \mathrm{~km}$ spot in spite of tides. The Kita is classified as a weak and partially-mixed estuary based on the classifications of Hansen \& Rattray (1966) and Suga (1979) due to the result of figure 2.

Figure 3 presents temporally-changed vertical profiles of salinity at $0 \mathrm{~km}$ on October 10, 1999. The upper interface between fresh and sea waters is considered 10-15 psu. In spring tide, the front of the salt water wedge reaches to 5$6.5 \mathrm{~km}$ upstream. In neap tide, it attains to $7 \mathrm{~km}$ upstream in both high and low waters. Water temperature and $\mathrm{pH}$ showed similar distribution forms to salinity, and stratification between fresh and the sea waters appear.

Temperature of the lower sea water is a little higher than that of the upper fresh water. The value of $\mathrm{pH}$ was 6.7 in the minimum and 8.3 in the maximum.

Chl-a, TN and TP were time- and space- dependent, and water bodies in high concentration existed patch-like. Mean values of Chl-a, $\mathrm{TN}$ and TP were in the order of magnitude, $1 \mu \mathrm{g} /$ $1,0.1 \mathrm{mg} / \mathrm{l}$ and $0.01 \mathrm{mg} / 1$, respectively. Dyer (1988) pointed out that the front of a salt water wedge in a weak or partially-mixed estuary as the Kita, tends to accumulate suspended solids by residual circulation as a result of the movement of seawater going up to the upper layer. Such movement in a salt water wedge makes suspended solids and phytoplanktons accumulate and DO consumption augment in the front of the salt water wedge where is for $5 \sim 6 \mathrm{~km}$ reach (see fig. 4 ). Figure 5 indicates DO distributions at $5 \mathrm{~km}$ point on Oct.10 ( spring tide) and Nov.29 ( neap tide). In the spring tide, DO of the upper water layer had more than $7 \mathrm{mg} / 1$ during the observation periods, and DO of the lower water in the ebb tide had 4-5mg/l, which was not anoxic. Turbidity in the Kita is several degrees usually so that extreme oxygen consumption in both the front of the salt water wedge and its inside is not expected. In the neap tide, comparatively clear stratification between fresh and sea waters is formed for a long term by weak mixing between the upper and the lower layers, and DO lowered more than that in spring tide.
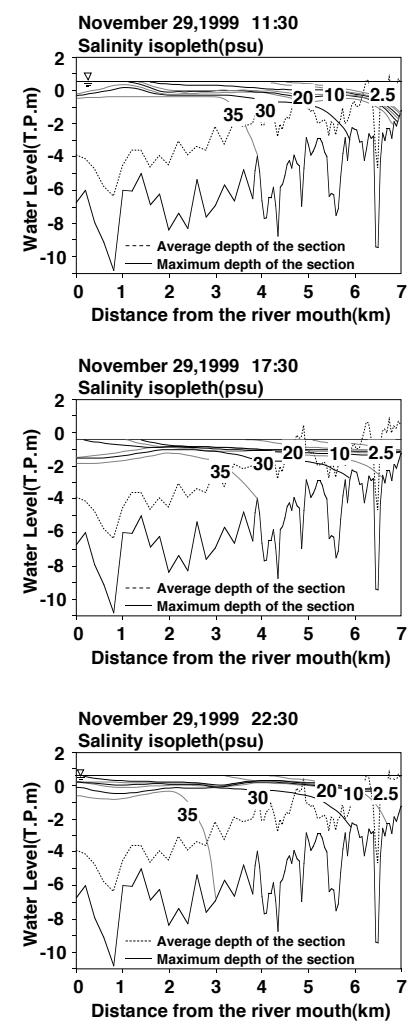

Fig.2 Longitudinal distributions of salinity along the Kita during spring (left) and neap(right) tides

\section{Habitat of Deiratonotus japonicus and consideration}

Figure 6 shows the observation points of $D$. japonicus. The distribution of $D$. japonicus extends from $1.3 \mathrm{~km}$ to $6.5 \mathrm{~km}$. D. japonicus inhabits not uniformly but patch-like due to its preference. In addition, the front of the 

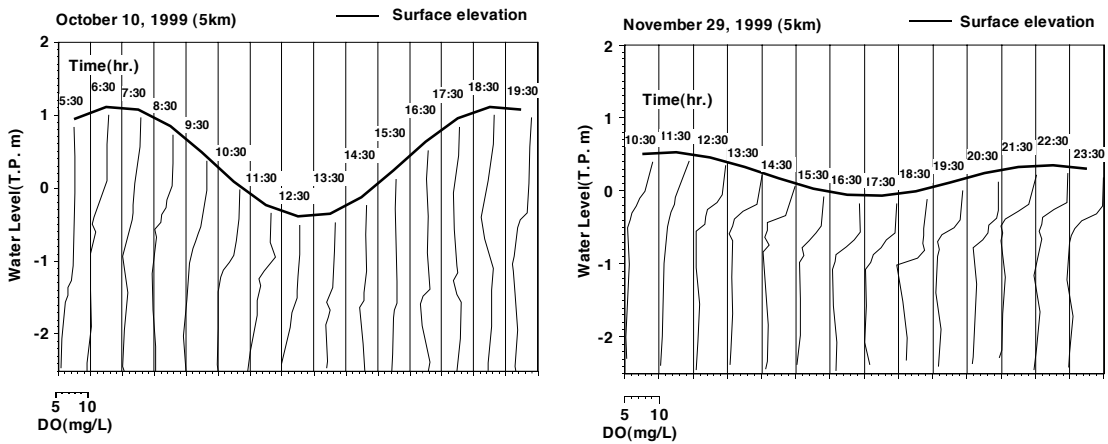

Fig.5 Temporal DO profiles with depth at $5 \mathrm{~km}$ in spring(left) and neap(right) tides.
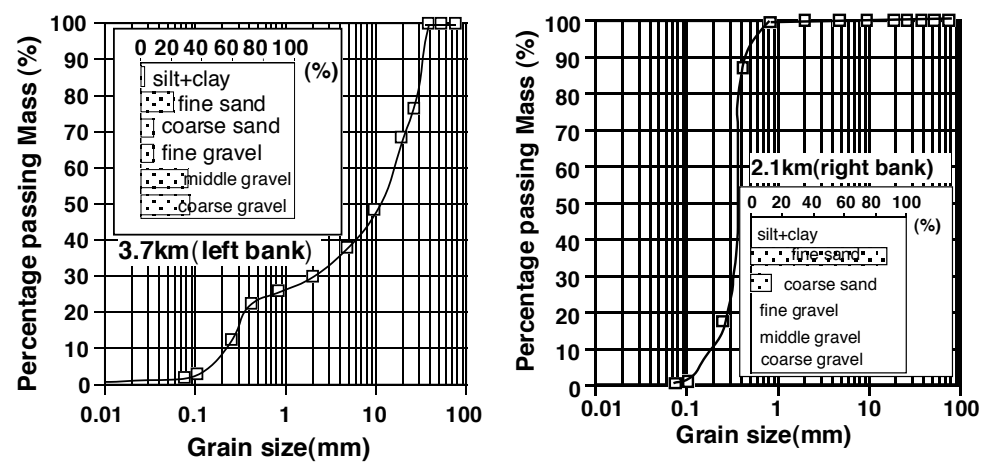

Fig.7 Survey of riverbed materials at existence place(left) or non-existence one(right) of D. japonicus.

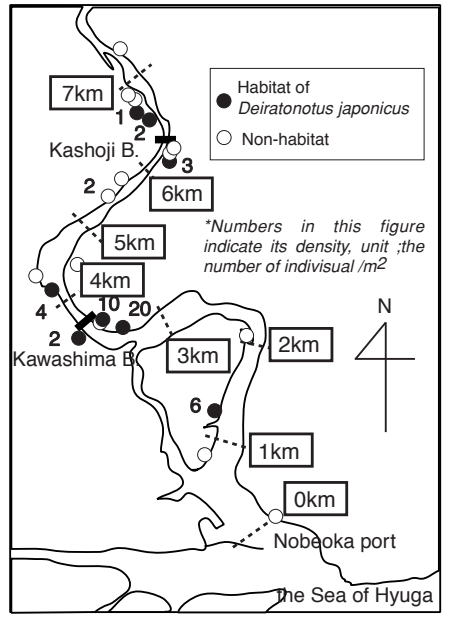

Fig.6 Spatial distribution of D.japonicus.

Table 1 Testing statics

\begin{tabular}{c|c|c|c} 
& Existence & $\begin{array}{l}\text { Non- } \\
\text { Existence }\end{array}$ & Total \\
\hline $\mathrm{d}_{50} \geq 4.75 \mathrm{~mm}$ & A & B & A+B \\
\hline $\mathrm{d}_{50}<4.75 \mathrm{~mm}$ & $\mathrm{C}$ & $\mathrm{D}$ & $\mathrm{C}+\mathrm{D}$ \\
\hline Total & $\mathrm{A}+\mathrm{C}$ & $\mathrm{B}+\mathrm{D}$ & $\mathrm{n}$
\end{tabular}

Testing statics $\mathrm{T}=\frac{(\mathrm{AD}-\mathrm{BC}-\mathrm{n} / 2)^{2} \mathrm{n}}{(\mathrm{A}+\mathrm{B})(\mathrm{C}+\mathrm{D})(\mathrm{A}+\mathrm{C})(\mathrm{B}+\mathrm{D})}$

saltwater wedge is in accordance with the upper limit of its habitat. This means that salinity is a key factor for the habitation of $D$. japonicus.

Figure 7 presents some examples of the grain size accumulation curve of riverbed materials in the habitat and non-habitat points of $D$. japonicus. The habitation point of $D$. japonicus depends on the existence of riverbed materials with middle sized gravel, whose size ranges from $4.75 \mathrm{~mm}-19 \mathrm{~mm}$, or larger. This means that riverbed materials larger than the middle play an important role in their hiding (cover) and inhabiting. Mean diameter $d_{50}$ may use as a representative of riverbed material characteristics, which is obtainable from a grain size distribution curve. To estimate the relation between the size distribution of riverbed materials and the habitat of D. japonicus, we applied the independent test of statistical hypothesis. Null hypothesis $\mathrm{H}_{0}$ in this case is made that "the mean diameter $\mathrm{d}_{50}$ of the riverbed materials larger than the middle is independent on the habitat of $D$. japonicus." As a result of calculation as shown in Table 1, testing statistics $\mathrm{T}$ which is considered revision of Yates in the case of the frequency less than 5 was 2.93 , where it was $A\left(d_{50} \geqq 4.75 \mathrm{~mm}\right.$, existence $)=6, B\left(d_{50} \geqq\right.$ $4.75 \mathrm{~mm}$, non-existence $)=3, \mathrm{C}\left(\mathrm{d}_{50}<4.75 \mathrm{~mm}\right.$, existence $)=0, \mathrm{D}\left(\mathrm{d}_{50}<4.75 \mathrm{~mm}\right.$, non-existence $)=2$, number of sample, $\mathrm{n}=11$. Then, if the level of significance $\alpha$ is $0.10, \chi_{1}^{2}(0.10)=2.71$ from $\chi_{1}^{2}$ distribution of the degree of freedom 1. Therefore, it is $\mathrm{T} \in \chi_{1}^{2}(0.10)$, and the null hypothesis $\mathrm{H}_{0}$ was rejected. In other words, it is supposed that "a mutual relationship exists between the habitat of D. japonicus and the riverbed materials having particle size of larger than the middle gravel." However, there are still some problems such as less number of the samples, the lower level of significance, inadequate collection conditions (tide, water depth, water current, and season) of D. japonicus, and less data obtained by experiments.

Figure 8 gives a long term change of salinity at both edges in the habitation area of D. japonicus $(1.3 \mathrm{~km}$ and $6.5 \mathrm{~km} \mathrm{spot}$ ). Water depth as a reference of the low water level in spring tide is also shown in the figure. It is found that $D$. japonicus inhabits places exposed to both sea and fresh waters. This means that there is a tolerance to salinity. An experimental result on the tolerance of $D$. japonicus against salinity is depicted in figure 9 . D. japonicus can not inhabit under a salinity of $0.5 \mathrm{psu}$ ( for fresh water ) for a long term, thought no difference of the survived terms between 10psu ( for brackish water) and 30psu ( for seawater ) was seen. This means that it can survive for a long term under salinity higher than 10psu. Actually, in the places where D. japonicus inhabits as shown by figure 8 , salinity is not kept constant for a long time.

Figure 10 compares salt and water temperatures of each spot with the population density of $D$. japonicus. In the figure, the variation and the mean value of salinity and water temperature of $0.1 \mathrm{~m}$ lower from the water surface on Oct.10, 1999 are shown as one example that D. japonicus inhabits close to the water surface of each cross- 

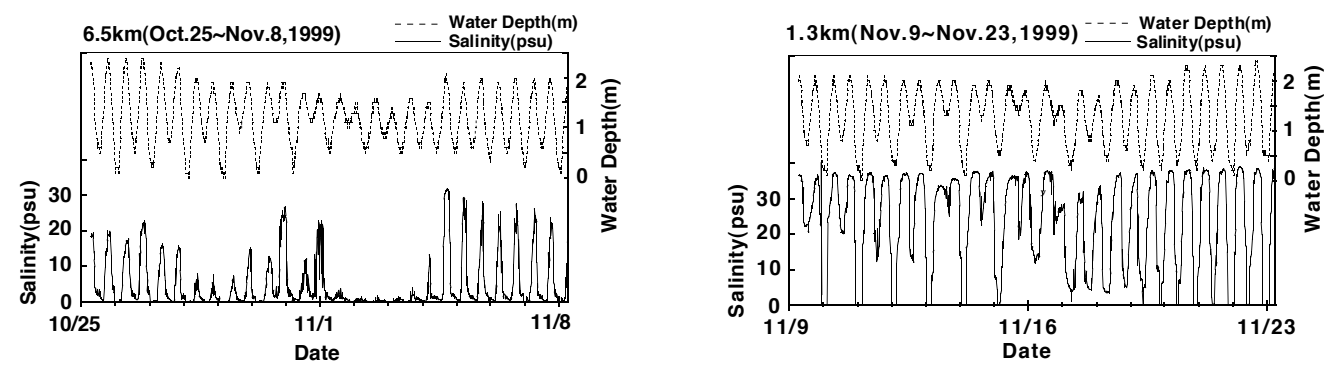

Fig.8 Time variation of salinity and water depth(1.3 and $6.5 \mathrm{~km}$ points)

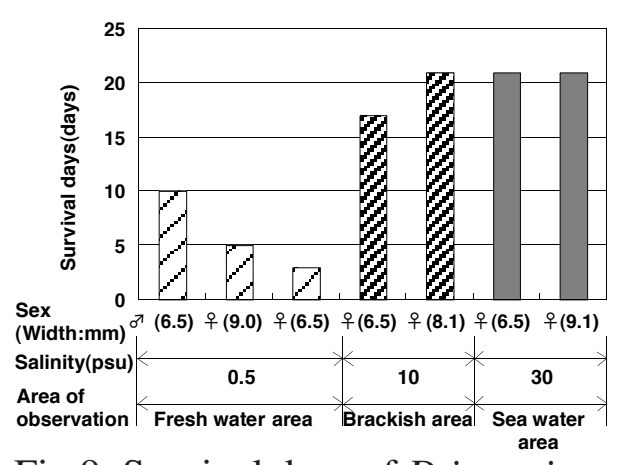

Fig.9 Survival days of D.japonicus by the difference of salinity

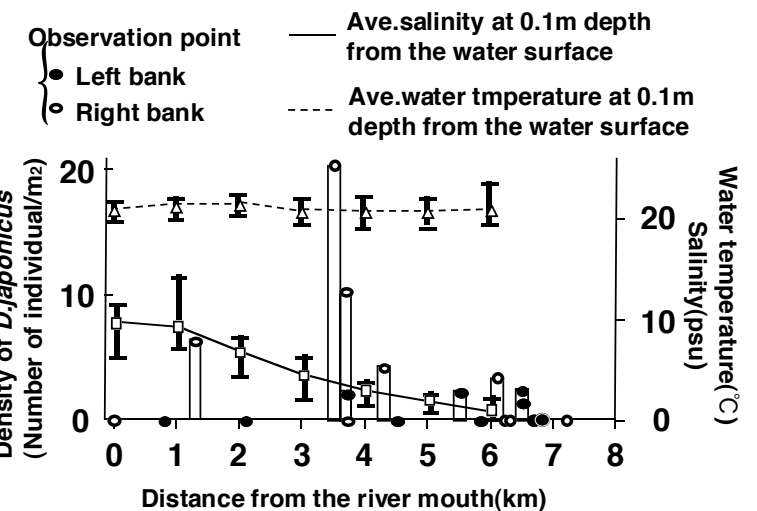

Fig.10 Relation between water quality and population density of D. japonicus along distance from the river mouth

section. Though the environment factors which affect habitat of $D$. japonicus are not only salinity and water temperature. Furthermore, it can be seen that the habitat distribution of $D$. japonicus seems to have an extreme value around $3-4 \mathrm{~km}$ from the river mouth due to the histogram of population density of D. japonicus, and the shape of population density looks like a bell shape.

\section{Water quality and habitat of Deiratonotus japonicus in the transverse direction}

As a result of the population distribution, D. japonicus is found to inhabit much around the Kawashima Bridge in the lower left bank of $3.75 \mathrm{~km}$. On the other hand, the habitation ranges from close to the water surface of the bank to $1 \mathrm{~m}$ depth. However, at the bank slope, riverbed materials are not uniform and water depth changes every hours shown in photo 2 (the Kawashima Bridge, the lower part of the left bank). So the distribution of $D$. japonicus to the transverse direction and water quality were investigated to examine influences to the preference of $D$. japonicus in habitation . The observation spots were the $3.75 \mathrm{~km}$ left bank and the $5.75 \mathrm{~km}$ right bank. Topography in the $3.75 \mathrm{~km}$ left bank was tide poollike.

Figure 11 shows the relation between the habitat of $D$. japonicus, water depth, salinity, DO and the mean diameter of riverbed materials at the $3.75 \mathrm{~km}$ left bank. Figure 12 indicates variations of salinity in the each spot in the cross direction. The population density of D. japonicus in 2000 was not higher, compared with

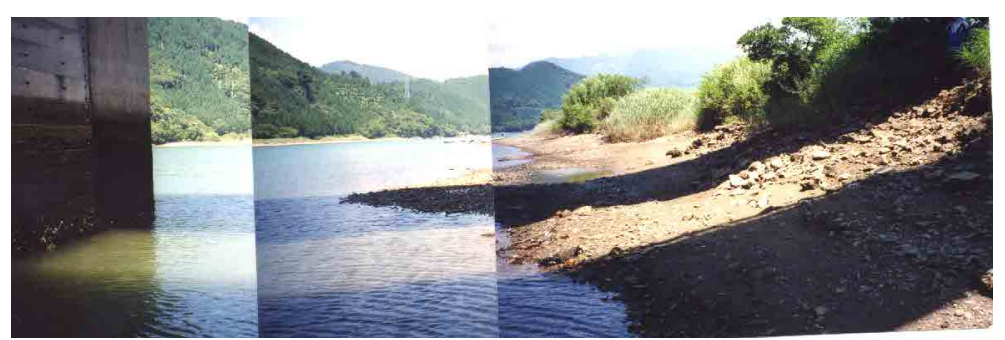

Photo 2 The lower part of the left bank under the Kawashima Bridge
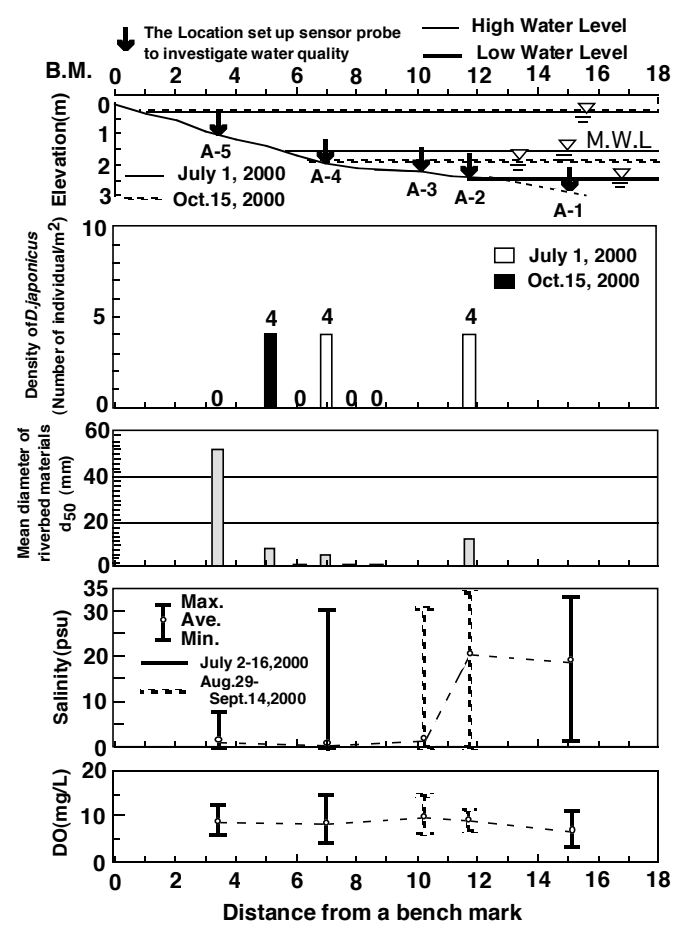

Fig.11 Water quality and density of D.japonicus in a cross directtion. 
the results in 1999. This might result from digging construction of the bank at the $3.75 \mathrm{~km}$ left bank. This survey also showed a similar tendency that $D$. japonicus inhabits preferably on riverbed materials larger than the middle sized gravel. However, even if the size of riverbed materials is larger than the middle sized gravel, habitation is not confirmed at the spot where is higher than an average tide level. DO changes due to tide level, but it is an average of $8 \mathrm{mg} / \mathrm{l}$ everywhere on the slope. This condition is adequate in habitation of $D$. japonicus.

\section{CONCLUSION}

Preference of $D$. japonicus on habitation was discussed based on the relation between characteristics of water quality and hydraulic factors, and the habitat of $D$. japonicus in the tidal area of the Kita. As a result, salinity, water temperature, and riverbed materials are important as environment factors on the habitat of $D$. japonicus. Especially, it is considered that riverbed materials play

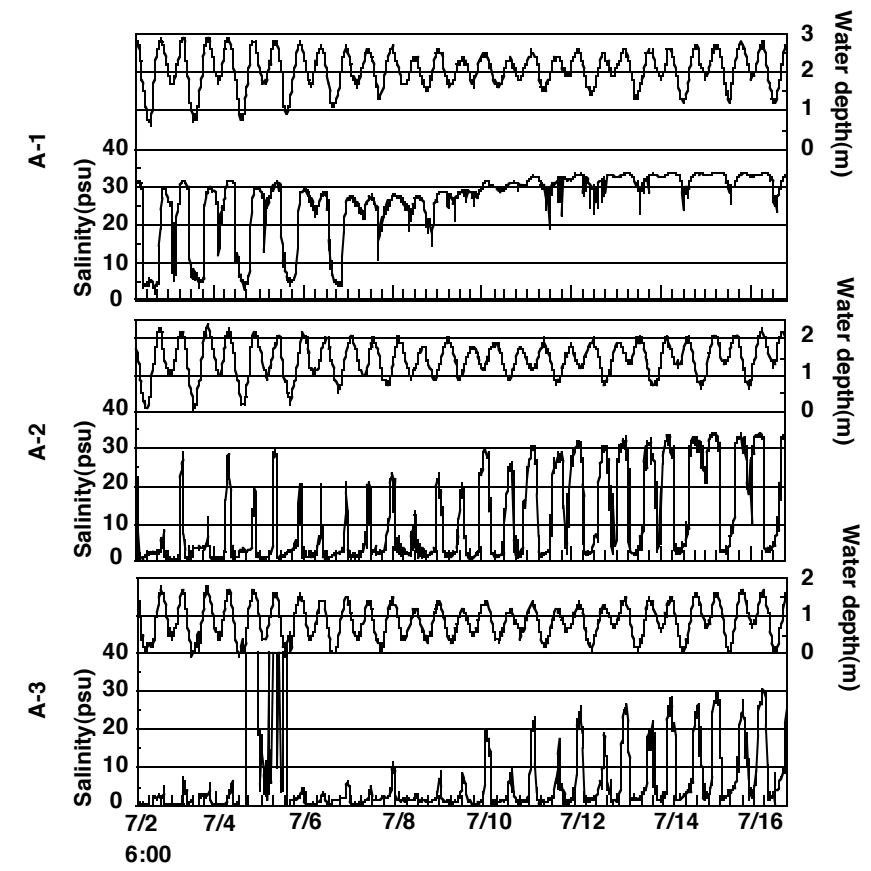

Fig.12 Time variation of salinity and water depth of left bank at $3.75 \mathrm{~km}$ point. an important role of their hiding place (cover). On the preference of the habitation of $D$. japonicus, hydraulic factors (water depth, current velocity and resident time of water, etc.) in micro- habitat and feeding place ground (diatom attached on the gravel, etc.) are to be considered, and adequate analytical methods to express spacial distributions of population density and habitat are further targets on this research.

\section{ACKNOWLEDGMENTS}

We would like to thank River Ecology Research Group of Japan for funding this research. This study was also supported in part by a Grant in Aid for Fundamental Scientific Research (No.12750466). Furthermore, we would also like to acknowledge precious information by Dr. Yuichi Ono, Dr. Tetsuro Hamamoto and field works by Dr. Keisuke Murakami, Nobeoka work office of Ministry of Land, Infrastructure and Transport, and Nobeoka work office of Miyazaki prefectural Government.

\section{REFERENCES}

Dyer, K. R. (1988): Fine sediment particle transport in estuaries, In; Physical Processes in Estuaries, SpringerVerlag, pp.295-310.

Hansen, D.V. and Rattray, M. (1966): New dimensions in estuary classification, Limnol. Oceanogr., Vol. 11, pp.319-326.

Inoue, K., Tanaka, M., Sakaguchi, T. and Nishizawa, K. (1993): Salinity intrusion analysis in estuarine river, Annuals, Disaster Prevention Res. Inst., Kyoto Univ., No.36 B-2, pp.411-423.(in Japanese)

Kobayashi, S.(1995): Many variable quantities analysis of ecological community, Sojushobo, 194p.(in Japanese)

Kyushu region construction station \& River front development research (1999):Report of the Kita River, pp.(91)-(9-3).(in Japanese)

Schijf, J.B. and Schönfeld,J.C. (1953):Theoretical conditions on the motion of salt and fresh water, Proc. Minnesota Int. hydro. Conf. I.A.H.R., pp.321-333.

Suga, G,(1979):Study on the hydraulics of the saltwedge in a tidal river, Public Works Res. Inst. document, 1537, pp.168-169.(in Japanese) 